\title{
Health Status and Access to Health Services in Indian Slums
}

\author{
Indrani Gupta ${ }^{*}$, Pradeep Guin ${ }^{2}$ \\ ${ }^{1}$ Health Policy Research Unit, Institute of Economic Growth University of Delhi Enclave, North Campus, \\ Delhi, India \\ ${ }^{2}$ School of Public Policy, University of Maryland, Baltimore County (UMBC), \\ Baltimore, USA \\ Email: ${ }^{*}$ ig.indrani@gmail.com, pradeep.guin@gmail.com
}

Received 29 December 2014; accepted 13 February 2015; published 16 February 2015

Copyright (C) 2015 by authors and Scientific Research Publishing Inc.

This work is licensed under the Creative Commons Attribution International License (CC BY). http://creativecommons.org/licenses/by/4.0/

(c) (i) Open Access

\section{Abstract}

This paper analyzes the state of health and access to health services among the urban poor in India. Analysis is based on data from a primary survey conducted among 2000 households, covering 10,929 individuals from four cities of India. Summary statistics and regressions (using STATA) are used for data analysis. Results show lack of government facilities and services, a very high preference for private health facilities, high expenses especially in private but also in public facilities, and a perception that private facilities are offering high quality services as important concerns. An econometric analysis of the determinants of acute illness indicates the insufficiency of basic amenities like sanitation, garbage disposal and potable water. Together with the lack of availability of government health facilities in the vicinity, these results indicate continued vulnerability of the urban poor, and the need for urgent government action.

\section{Keywords}

India, Urban Poor, Access to Health Services, Slums, Public Policy

\section{Introduction}

Globally, while a significant number of individuals have moved out of slums, the absolute number of slum dwellers has actually increased over the years. Latest estimates from developing regions indicate that the proportion of urban population living in slums has declined from 39 percent in 2000 to 33 percent in 2012. However, the absolute number of slum dwellers in urban areas from this region has increased from 760 million to 863

*Corresponding author. 
million for the same period [1]. Comparative slum statistics from India revealed the same pattern; percent of slum dwellers marginally decreased from 24 (in 2001) to 22 percent (in 2011), while absolute numbers increased from 52 million to 65 million [2]. An earlier report from UN-HABITAT highlights that the urban poor, especially the slum dwellers in developing countries, is as badly off, if not worse off, than their rural counterparts [3]. It also provides evidence of "a tale of two cities within one city" - one part of the urban population that has all the benefits of urban living, and the other part, the slums and squatter settlements, where the poor often live under conditions worse than those of their rural counterparts [3]. Such living conditions also mean that the slum dwellers are likely to die earlier than the rest of the population of the city, and have fewer opportunities to improve their human development parameters [4].

The urban health infrastructure in India is neither appropriate nor adequate, and has not really been able to meet the needs of the urban population, especially the poor [5]-[9]. Recent reports indicate that there are 1083 Urban Family Welfare Center (UFWCs) ${ }^{1}$, and 871 Health Posts (HPs) ${ }^{2}$ that cater to 377 million people living in the urban areas in the country [9]-[11]. This translates to one UFWC/HP per 192,992 urban populations, compared to the norm of one centre for every 50,000 persons, indicating severe accessibility issues. Other estimates indicate the need for an additional requirement of 500 urban health and family welfare centers to meet the current needs of urban poor [12].

The Eleventh Plan document acknowledges that there has been an increase in the number of urban poor, and that the civic authorities will have a daunting task in responding to their health and infrastructural needs [13]. With poor living conditions, no backup savings, food stocks, or social support system, their vulnerability to illness increases multiple folds. Despite the presence of government hospitals and other health care facilities in the urban areas, the slum dwellers have limited access to these facilities. The initiatives to address urban health concerns have been limited and fragmented in the country, and a recent analysis points out clearly that the government has no proper implementation plans for the urban health and lack of evidence-based policies continues to be a main feature of urban health [14]. The plan to launch a National Urban Health Mission has been scrapped and in its place a unified National Health Mission is being visualized. Currently, the bulk of the expenditure for urban family welfare services still comes from National Rural Health Mission (NRHM) funds. In 2011-12, only about 1.2 percent of the total expenditure under NRHM was on urban family welfare services [15]. Of course, there are other components for the urban areas, like the urban slum projects, under the Reproductive and Child Health (RCH)-II project. However, overall, investment on urban infrastructure and especially improvements in access for urban poor is very negligible in the Family Welfare outlay of the Ministry of Health and Family Welfare, Government of India.

A significant body of literature exists on the various aspects of urban health like maternal and child health, health of the aged, treatment-seeking behavior, etc. [16]-[22]. However, the focus has been narrow in most such analyses that are also often based on case studies or small samples drawn from a few geographical areas.

Recognizing that serious infrastructure bottlenecks exist in cities and towns in India that prevent the urban poor from reaching their economic potential, the Government of India launched the Jawaharlal Nehru National Urban Renewal Mission (JNNURM) ${ }^{3}$ in 63 cities and towns. To generate evidence, the Ministry of Housing and Urban Poverty Alleviation, Government of India, and the United Nations Development Program (UNDP) initiated a project on "National Strategy for the Urban Poor" in 2006, which was based on large scale primary survey in four cities/towns in India, and covered issues around poverty, labor market, water and sanitation issues, and access to health services.

Using this data, the current study was undertaken to understand the access to health services of the urban poor and link access to their health status.

\footnotetext{
${ }^{1}$ It provides family welfare services in urban areas since the early 1950s, and is equipped to provide contraceptive supplies. Based on the population covered by each UFWC, it is classified in three types, and has different staffing patterns. Type I covers a population of $10-25$ thousand, Type II between 25 - 50 thousand and Type III above 50 thousand.

${ }^{2}$ It was introduced in 1983 with a view to provide service delivery outreach, primary health care, family welfare and maternal and child health $(\mathrm{MCH})$ services in urban areas. It is classified into four types-A, B, C and D, but with lesser population base compared to UFWC.

${ }^{3}$ It was the single largest initiative ever launched by the Government of India focusing on the urban infrastructure development and basic services to the urban poor. This 7 years (2005-2012) mission, launched on $3^{\text {rd }}$ December 2005, was implemented across 63 select towns/cities in the country.
} 


\section{Materials and Methods}

The towns/cities selected for the survey were Jaipur, Ludhiana, Mathura and Ujjain, and these were parts of the 63 select towns/cities in the country under the above-mentioned project [23]. Five hundred households each from among twenty-five clusters (22 notified ${ }^{4}$ and 3 non-notified ${ }^{5}$ ) from each of the four cities were selected based on a three-stage stratified random sampling technique. Information was collected for 10,929 individuals from among the 2000 selected households. The survey was carried out between November 2006 and April 2007 and included slums notified by the government, as well those that are not notified and therefore generally not targeted for government services and schemes.

The health survey was designed to collect data on Out Patient Department (OPD) visits for the reference period of last one month and hospitalization (inpatient) for the last six months of the survey. Details were sought on illnesses and treatment-seeking behavior of the slum dwellers including expenditure. It also included a section on pregnancy and childbirth. Attempts were made to understand the patients' valuation of the quality of health services for OPD, hospitalization as well as pregnancy-related services.

The analysis is based on simple descriptive statistics and a multivariate analysis, the latter to enable a better understanding of the factors that were influencing the health outcomes in the slums.

\section{Results}

\subsection{Socio-Economic Profile of the Sample}

Table 1 presents the basic socio-demographic characteristics across four sites. Most of the slum dwellers migrated from other parts of their home state to the current location, except in Ludhiana where 16 percent and 8 percent are from Uttar Pradesh and Bihar, respectively (figure not in table). The economic status of the respondents is based on the ownership of consumer durables, and is divided into three categories-low, medium and high - based on relative weights of asset holding. Thus, the economic status indicates the relative status of the respondents within slums.

\subsection{Health Services in Slums}

Heads of households were asked about the existence and type of health facilities in the slum they were residing in. A majority (68\%) of the 1998 heads who responded to the questionnaire said there were only private health facilities in the slums. About four percent said there were government facilities, and about 14 percent said there were both public and private health facilities. This means, as many as 82 percent respondents indicated the presence of private facilities in their slums.

\subsection{Outpatient Visits}

The sample yielded a morbidity rate of 13 percent. Since there were very few cases of second or third illness, the study analyses only those cases that have reported at least one illness in the reference period.

The National Sample Survey (NSS) $60^{\text {th }}$ round reports the proportion of ailing persons by residence status and sex during a period of 15 days: for urban India the figure was 99 per 1000 person, giving a morbidity rate of about 10 percent, which is somewhat lower than the rate estimated from the current survey of slums [24]. This is consistent with the view that the slum dwellers as a whole are relatively less healthy than the general population. Similarly, the results were comparable with the NSS estimates on diarrhea and fever, which were reported as the two most common ailments (47.3\% and $31.2 \%$ respectively).

Around 90 percent of the ill individuals (1304 out of 1456) consulted a doctor for treatment. Of the remaining who did not seek doctor's help, a majority resorted to self-medication (71.7\%), while some thought it was not necessary (27.6\%). Almost no one reported distance or lack of availability of good doctors as reasons for not accessing treatment, again indicating the collective perception about availability and quality of health services in these slums.

\footnotetext{
${ }^{4}$ All specified areas in a town or city notified as "Slum" by State/Local Government and UT Administration under any Act including a "Slum Act".

${ }^{5}$ All areas recognized as "Slum" by State/Local Government and UT Administration, Housing and Slum Boards, which may have not been formally notified as slum under any Act.
} 
Table 1. Selected social and demographic indicators by sites.

\begin{tabular}{|c|c|c|c|c|c|}
\hline Background characteristics & Jaipur & Ludhaina & Mathura & Ujjain & Total \\
\hline \multicolumn{6}{|l|}{ Sex } \\
\hline Male & 52.3 & 56.7 & 53.3 & 51.2 & 53.3 \\
\hline Female & 47.7 & 43.3 & 46.7 & 48.8 & 46.7 \\
\hline \multicolumn{6}{|c|}{ Employment status for those who reported any work in the past 12 months $^{a}$} \\
\hline Daily wage labor & 41.0 & 20.8 & 32.7 & 56.4 & 38.7 \\
\hline Regular salaried & 34.7 & 46.5 & 32.0 & 24.0 & 33.9 \\
\hline Self employed & 24.3 & 32.8 & 30.3 & 13.3 & 24.6 \\
\hline Other ${ }^{\mathrm{b}}$ & 0.0 & 0.0 & 5.0 & 6.3 & 2.8 \\
\hline \multicolumn{6}{|c|}{ Education level for age group 18 and above ${ }^{c}$} \\
\hline Non-literate & 40.4 & 28.8 & 37.6 & 34.5 & 35.5 \\
\hline Literate but no formal education & 9.1 & 2.1 & 0.8 & 2.2 & 3.6 \\
\hline Primary & 18.2 & 14.4 & 12.3 & 23.8 & 17.1 \\
\hline Secondary & 24.4 & 40.0 & 27.4 & 29.2 & 30.0 \\
\hline Senior secondary & 4.4 & 8.2 & 9.6 & 6.1 & 7.1 \\
\hline Graduate and above & 3.2 & 6.1 & 11.3 & 4.1 & 6.2 \\
\hline Other $^{\mathrm{d}}$ & 0.4 & 0.5 & 1.0 & 0.2 & 0.5 \\
\hline \multicolumn{6}{|l|}{ Economic status } \\
\hline Low & 27.5 & 27.6 & 33.2 & 36.2 & 31.1 \\
\hline Middle & 51.0 & 42.9 & 39.6 & 52.6 & 46.5 \\
\hline High & 21.5 & 29.5 & 27.2 & 11.2 & 22.4 \\
\hline $\mathbf{N}$ & 2979 & 2425 & 2980 & 2545 & 10,929 \\
\hline
\end{tabular}

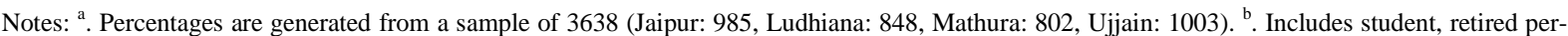
sons, unpaid family worker (full \& part time), and others. ' . Percentages are generated from a sample of 6311,18 years and above (Jaipur: 1630 , Ludhiana: 1507, Mathura: 1659, Ujjain: 1515). '. Jaipur, Ludhiana, Mathura and Ujjain are towns/cities from Rajasthan, Punjab, Uttar Pradesh and Mad-

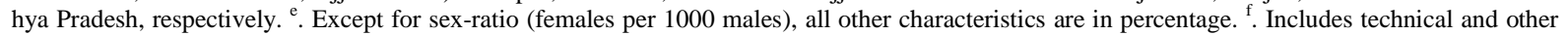
diplomas/certificates, professional and vocational certificates, and others. Source: Primary survey conducted for the study.

A majority (80\%) of those who consulted a doctor preferred private facilities, of which about half visited private clinics, and 30 percent went to private hospitals and around 17 percent went to government hospitals. Almost no respondent chose to visit government dispensary for his or her conditions. The ease of access to private health facilities was indicated from the fact that 62 percent of the people reported facilities to be within $2 \mathrm{~km}$ from their residence. Also, a majority of the individuals could walk to the facility, indicating their relative accessibility. The picture was quite similar across sites (data not presented here).

While designed to be free, users of the government facility on an average paid more for all the components except consultation and transportation (Table 2). Additionally, expenditure on drugs and medicines was highest in both the categories. Higher diagnostic costs in government facilities probably indicate the practice among such facilities of sending their patients outside—-mostly in private sector—for their diagnostic tests.

\section{Quality of Service in Outpatient Visits}

A majority of the respondents defended their choice of providers based on their perceptions of quality. Around 88 percent of the sick individuals who consulted a doctor were satisfied with the treatment and their behavior; around 81 percent reported being satisfied with the behavior of other staff. Similarly, a majority of individuals 
Table 2. Average expenditure (in US\$) for first visit on accessing treatment for acute illness.

\begin{tabular}{cccc}
\hline Components & Total & Govt. facility & Private facility \\
\hline Transport & 0.15 & 0.13 & 0.13 \\
Consultation & 0.39 & 0.18 & 0.46 \\
Drugs and medicines & 2.72 & 3.76 & 2.44 \\
Diagnostics & 0.84 & 1.54 & 0.72 \\
Other & 0.16 & 0.31 & 0.13 \\
Total & 4.26 & 6.54 & 4.74 \\
\hline
\end{tabular}

Source: primary survey conducted for the study.

(80\%) were satisfied with the infrastructure of the OPD facility they visited. The overall rating of OPD services indicated that almost 79 percent of the respondents thought that it was good, and 17 percent rated it as average (data not presented here).

As for reasons for selecting a particular doctor during an OPD visit (not reported in table) the provider being a good doctor was considered as the most important reason for selection. There were also some other reasons that were not uniform across four sites. For example, 23 percent of the patients form Ujjain considered treatment cost, whereas 28 percent of the patients from Ludhiana considered proximity to doctor's office or health center as factors other than good doctor that influenced the choice for selecting a particular doctor.

\subsection{Hospitalization}

There were 245 cases of hospitalizations. Diarrhea, stomachache and fever were the most common reasons for hospitalization. Almost the entire sample of hospitalized individuals said they had to undertake only one visit to the hospital for their condition.

The division between public and private hospitals was roughly equal, indicating a much larger use of public hospitals in hospitalization cases, compared to OPD cases. In about 40 percent of the cases, individuals traveled more than $5 \mathrm{~km}$ to get to the hospital. Around 80 percent of the individuals could reach the hospital in less than 40 minutes.

About 67 percent of the respondents stated good doctors as the most important reason for selecting this hospital, followed by cost factor or inexpensiveness (26\%); proximity was not found to be as important for selection of a facility.

Regarding quality of treatment, a majority stated that they were satisfied with the treatment (82\%); only about five percent were dissatisfied with the hospital, and the rest were indifferent. Similarly, a slightly lower, but still a large proportion of individuals (77\%) said they were satisfied with the nursing care received at the hospital. About 80 percent of the respondents were satisfied with the behavior of doctors and 79 percent with the behavior of other staff at the hospital. Around three-fourths (74\%) of the respondents felt that the inpatient facilities were good, 21 percent felt they were average, and around five percent rated the facilities as poor.

\subsection{Pregnancy and Childbirth}

Since family welfare program has received a lot of emphasis in India, it was thought important to see whether services were available for the slum respondents. In all, there were 198 cases of pregnancy in the sample in the reference period of one year. There were few cases of multiple pregnancies, and in 181 cases, there was only one pregnancy, which forms part of the analysis here.

When asked whether there was any visit by a health worker during the pregnancy, 81 percent said a health worker had never visited them. Only about nine percent of women said there were regular visits, and 10 percent said there were occasional visits.

About half of the respondents had regular antenatal check-ups, while 25 percent had occasional check-ups. Of those who did not ever have any check-ups (47 cases), the most stated reason (57\%) was that it was not necessary. Another 25 percent women said they did not have knowledge about such check-ups. Very few women 
stated the lack of nearby facilities as a reason for not getting regular check-ups done.

When asked about the source of antenatal check-ups from among women who had one pregnancy during the period (134 out of 181 women), about 57 percent stated private hospitals as their source, indicating the presence of varied private sources for such visits. About 30 percent visited government dispensaries for their check-ups while only around 8 percent visited antenatal clinics. These statistics reconfirm the lack of urban focus of the government's family welfare services, especially for the poor.

The quality of antenatal check-up was determined by two factors: whether facility was open when visited during office hours and availability of health personnel at the time of visit. Almost all the women respondents using this facility and having visited during office hours said that it was open at the time of the visit, and about 81 percent said that health personnel were available every time they visited. Seventy-seven percent rated the overall experience as good, while the remaining rated it as average. No respondents rated the experience as poor. Again, private facilities score over government ones for their accessibility and availability.

The questionnaire also asked women who had one or more childbirths in the preceding year about the place of delivery and the quality of the facilities. There were 211 deliveries in the entire sample for the reference period of one year. Despite the stress on institutional deliveries by the government, around 46 percent of the deliveries were conducted at home. Twenty five percent deliveries were at private hospitals, followed by 19 percent at government hospitals, and about nine percent at post-partum centers or health posts.

Around 83 percent said they would go back to the facility out of their choice. Overall, about 73 percent rated their experience as good, and about 26 percent said they were indifferent. Those who did not have a delivery at a health facility cited high expenditure (37\%) and lack of nearby facilities (17\%) as reasons for non-institutional delivery.

\subsection{Determinants of Acute Illness: A Multivariate Analysis}

In addition to quality of health services, the presence of basic amenities like electricity, water and sanitation have a significant impact on the health status of people, especially in the slums. The survey allowed a multivariate analysis of the determinants of the probability of acute illness, where the following variables were used as independent variables: age; gender; economic status proxied by asset-ownership and categorized as low, medium and high, based on number of assets owned; social status; presence of electric connection; quality of water; use of sanitary latrine for defecation and presence of choked open drains or choked public sewers in the neighborhood. The last four variables were included to control for hygiene and sanitation differences. Since no facility survey was undertaken, presence of health facilities was not included in the analysis. In any case the presence of health facilities is important in the analysis of treatment-seeking behavior and does not directly impact on occurrence of acute illness.

The summary statistics are given in Table 1 . As for the remaining variables, 93 percent of the households had electricity connection, 75 percent used a sanitary latrine for defecation, 21 percent had foul smelling water, and 58 percent had open drains or choked public sewers in their neighborhood.

A probit ${ }^{6}$ regression was estimated and the results are reported in Table 3. Rather than reporting the coefficients, which are difficult to interpret, the marginal effects are presented, i.e. the change in the probability for an infinitesimal change in each independent, continuous variable and the discrete change in the probability for dummy variables.

The results indicate that the poor have a 2.8 percent higher probability of illness compared to the non-poor ( $p<$ $0.01)$. Children and the elderly have a 1.7 percent $(p<0.05)$ and 7.5 percent $(p<0.01)$, respectively, higher probability of illness compared to the adults. Also, those who have foul smelling water supply in their household have a 4 percent higher probability of illness compared to those who do not $(p<0.01)$. Those who use sanitary latrines have a 1.3 percent lower probability of illness compared to those who use the open field or drain for defecation. Proximity to choked neighborhood drains increases the probability of illness by 1 percent compared to those who live away from it. While the magnitude of the two variables (i.e., sanitary latrines and chocked drains) explain their contribution to illness, these variables, however, are not significant. Gender or caste did not seem to influence morbidity among slum dwellers.

\footnotetext{
${ }^{6}$ In a probit model, the dependent variable $y_{i}$ can be only one or zero, and the continuous independent variable $x_{i}$ are estimated in: $\operatorname{Pr}\left(y_{i}=1\right)$ $=\mathrm{F}\left(\mathrm{x}_{\mathrm{i}}{ }^{\prime} \mathrm{b}\right)$, where $\mathrm{b}$ is the parameter to be estimated and $\mathrm{F}$ is the normal cumulative density function.
} 
Table 3. Probability of illness: probit regression results.

\begin{tabular}{ccc}
\hline \multicolumn{2}{c}{ (Dependent variable: illness, number of observations: 10,805$)$} & z-ratio \\
\hline Variable & Df/dX & $3.58^{* * *}$ \\
Poor & 0.028 & -0.52 \\
Caste (SC/ST/OBC) & -0.004 & 0.90 \\
Female & 0.006 & $2.42^{* *}$ \\
Child & 0.017 & $4.91^{* * *}$ \\
Elderly & 0.075 & 0.33 \\
Electricity connection & 0.004 & $4.92^{* * *}$ \\
Foul smell in water & 0.040 & -1.56 \\
Sanitary latrine & -0.013 & 0.06 \\
Choked open drains & 0.001 & 0.006 \\
\hline
\end{tabular}

Notes: Df/dX represents the change in probability. ${ }^{* * *} p<0.01,{ }^{* *} p<0.05,{ }^{*} p<0.10$. Source: primary survey conducted for the study.

\section{Discussion}

The results are consistent with past findings that urban slums are under-served by government facilities, with private providers and facilities scoring high on perceptions about quality [25]-[32]. Clearly, the cost differences between government and private facilities were not large enough to overcome other access and availability constraints of government facilities [33]-[36]. The presence of poor reproductive and child health services is an important finding that questions the efficiency of the existing mother and child health programme of the government.

The Commission on Macroeconomics and Health states that "access to medical care continues to be problematic due to locational reasons, bad roads, unreliable functioning of health facilities, transport costs and indirect expenses due to wage loss etc., making it easier to seek treatment from local quacks” [37]. While the Commission report did not focus particularly on urban health and the urban poor, the evidence from the current research seems to indicate that these findings are very relevant to urban areas as well. The Commission's facility survey indicate the overwhelming participation of private providers in provision, duplication of private and public facilities in many locations, non-standardization of treatment and payment protocols, an acute shortage of human resources, poor availability of obstetric care among many more findings [37]. This study corroborates these findings and also indicates that private providers are most likely to be present in the market for curative primary care, but for hospitalization and deliveries, their presence is relatively less. From the demand side, for bigger expenses, individuals still seem to be looking for low cost care, and if there are cheaper alternatives like government facilities, they were likely to visit those. These findings are consistent with earlier findings that for higher treatment cost, the government sector or other cheaper alternatives may still be preferred, but for OPD, an overwhelming majority goes to private providers.

The impacts of lack of basic amenities like sanitation, garbage disposal, and potable water on health on the one hand, and accessibility and quality issues of health facilities on the other, make the urban poor vulnerable to health shocks. The onus of slum development has been mostly on the government, and it does not seem as though it has succeeded to provide a clean environment and adequate basic facilities; in fact the situation has remained almost static for the past several years [38] [39].

Provision (as also financing) of health services has continued to be problematic in India and it has been difficult to change the efficiency of the system in any significant way over the years. The issues around urban health are complex and compounded by the presence of slums, which require additional and detailed planning on provision of basic amenities like water and sanitation. The lack of regulation on the private sector adds to the problem of supply gaps and quality concerns, and adds significance to the finding that private health care is the dominant mode of provision in urban slums [40] [41]. Thus, the consumer-satisfaction reported by the respondents in the study needs to be interpreted with caution in face of evidence of lack of quality, which may only point to 
lack of awareness and knowledge about affordable quality services.

Another key concern in this context is the presence of significant corruption in the delivery of public services, including health services. There are findings that document that health care is among the most corrupt services in India [42]. Recent reports of massive corruption in health funds received — both external and internal-confirm that the health sector is dealing with serious issues of fraud and misuse of funds meant for the underprivileged [43] [44]. Delhi—which has a large slum population—has also been in news for massive corruption and fraud in its municipal body (Municipal Corporation of Delhi), which is responsible for basic amenities as well as a significant number of health facilities [45].

Health policy in India continues to lack evidence-based planning on the one hand, and a need for serious action to improve accountability on the other hand. There is not much evidence to indicate that serious attempts at coordination and alignment among the various line ministries that impact on urbanization have been made; health, water and sanitation, land, infrastructure all are much more tightly integrated in the urban areas compared to the rural areas.

Some non-government organizations have, however, taken the lead together with government bodies to improve basic amenities in urban poor areas as well as making sure that accessibility to health services improve in such areas [46]. The use of public-private partnerships (PPP) as a method is also visible for example, from the partnership between the Urban Health Resource Centre and government bodies in urban areas like Agra [31]. A recent example of such public-private partnership (PPP) is the Government of National Capita Territory of Delhi’s (GNCTD) Mission Convergence Programme, locally called Samajik Suvidha Sangam. This USAID funded programme is an innovative PPP with participation from the local community organizations to improve the health and well-being of the urban poor of Delhi [47].

The Report of the Steering Committee on Urban Development and Management for the $12^{\text {th }}$ Five Year Plan set up by the Planning Commission gives a comprehensive analysis of reforms needed to set right the urban problems India is facing (Ministry of Housing and Urban Poverty Alleviation [48]. Needless to say that the recommendations in the report-while sound-require a serious overhauling of the system and may take much longer than anticipated. The very low availability of urban health services for the urban poor and the non-functioning of those that are available indicate a serious lapse on the part of the government in urban health planning. Suffice to say that despite some serious attention being paid by the central as well as state governments to improve the health situation in the urban slums, very little progress has been made so far. The abandoning of the earlier-proposed National Urban Health Mission and the new unified National Health Mission seem to suggest that the focus has shifted from urban health. Given the concerns around the National Rural Health Mission, a different and innovative approach is needed to tackle the urban health issues, to prevent further deterioration in health outcomes and inequities in the country.

\section{Acknowledgements}

This research is based on data collected under the survey carried out for the IEG-UNDP-GOI (Institute of Economic Growth-United Nations Development Programme-Government of India) for the project entitled "National Strategy for the Urban Poor".

We thank the participants of the Health Systems in Asia 2013 conference for their valuable comments. We acknowledge the expert research help provided by Devmani Upadhyaya.

\section{References}

[1] United Nations Human Settlements Programme (UN-HABITAT) (2013) Streets as Public Spaces and Drivers of Urban Prosperity. UN-HABITAT, Nairobi. http://mirror.unhabitat.org/pmss/listItemDetails.aspx?publicationID=3513

[2] The Registrar General \& Census Commissioner (Government of India) (2013) Primary Census Abstract for Slum. Office of the Registrar General \& Census Commissioner, New Delhi. http://www.censusindia.gov.in/2011-Documents/Slum-26-09-13.pdf

[3] United Nations Human Settlements Programme (UN-HABITAT) (2006) State of the World's Cities Report 2006/7. UN-HABITAT \& Earthscan, Nairobi \& London.

http://www.unhabitat.org/pmss/listItemDetails.aspx?publicationID=2101

[4] Moreno, E.L. and Warah, R. (2006) Urban and Slum Trends in the 21st Century. UN Chronicle, 43, 24-29.

[5] Gupta, I. (2006) Health of the Urban Poor: Progress and Challenges. Unpublished Monograph under UNDP-GOI Pro- 
ject “National Strategy for Urban Poor”, Presented to the Ministry of Urban Development, Government of India. Institute of Economic Growth, Delhi.

[6] Rajalakshmi, T.K. (2007) Urban Crisis. Frontline, 24, 88-90.

[7] Dhar, A. (2006) Demand to Include Urban Poor in Health Mission. The Hindu e-Paper. http://www.hindu.com/2006/09/12/stories/2006091212020300.htm

[8] John, D., Chander, S.J. and Devadasan, N. (2008) National Urban Health Mission: An Analysis of Strategies and Mechanisms for Improving Services for Urban Poor. Background Paper for National Workshop on Urban Health and Poverty, 2-3 July 2008. Ministry of Housing and Urban Poverty Alleviation, Government of India, New Delhi. www.iphindia.org/new/images/Publications/nuhm-background\%20paper.doc

[9] Agarwal, S., Satyavada, A., Kaushik, S. and Kumar, R. (2007) Urbanization, Urban Poverty and Health of the Urban Poor: Status, Challenges and the Way Forward. Demography India, 36, 121-134.

[10] Ministry of Health \& Family Welfare (Government of India) (2006) Draft Final Report of the Task Force to Advise the National Rural Health Mission on "Strategies for Urban Health Care”. Ministry of Health \& Family Welfare, New Delhi. http://mohfw.nic.in/NRHM/Task_grp/Tg_index.htm

[11] The Registrar General \& Census Commissioner (Government of India) (2011) Provisional Population Totals, Paper 2 of 2011, India, Series 1. Office of the Registrar General \& Census Commissioner, New Delhi. http://www.censusindia.gov.in/2011-prov-results/paper2/data_files/india/paper2_at_a_glance.pdf

[12] InfoChange India News \& Features (2008) India’s Urban Poor Need 40 mn Houses, 500 Health Centres: ASSOCHAM Report. InfoChange India News \& Features, Pune.

http://infochangeindia.org/200801236839/Urban-India/News/India-s-urban-poor-need-40-mn-houses-500-health-centre s-ASSOCHAM-report.html

[13] Planning Commission (Government of India) (2008) Eleventh Five Year Plan: 2007-12: Social Sector (Volume II). Oxford University Press, New Delhi.

[14] Gupta, I. and Mondal, S. (2014) Urban Health in India: Who Is Responsible? The International Journal of Health Planning and Management, Early View. http://dx.doi.org/10.1002/hpm.2236

[15] Ministry of Health and Family Welfare (Government of India) (2012) Statement Showing Revised Estimates vs. Actual Expenditures, Grant No. 46. Ministry of Health and Family Welfare, New Delhi. http://ccahealth.gov.in/Health/Admin/Attachments/AccountFiles/ProgressiveExpenditure/2011-201231-03-2012_As\% 20on\%20date\%20Exptd.\%20upto\%2031st\%20March.\%202012\%20\%20Provisional\%20Health,\%20NRHM.pdf

[16] Fry, S., Cousins, B. and Olivola, K. (2002) Health of Children Living in Urban Slums in Asia and the Near East: Review of Existing Literature and Data. Activity Report 109, Environmental Health Project, Arlington.

[17] Agarwal, S. and Taneja, S. (2005) All Slums Are Not Equal: Child Health Conditions among the Urban Poor. Indian Pediatrics, 42, 233-244.

[18] Agarwal, P., Singh, M.M. and Garg, S. (2007) Maternal Health-Care Utilization among Women in Urban Slum in Delhi. Indian Journal of Community Medicine, 32, 203-205. http://dx.doi.org/10.4103/0970-0218.36829

[19] Magadi, M.A. (2004) Maternal and Child Health among the Urban Poor in Nairobi, Kenya. African Population Studies, 19, 171-190. http://www.bioline.org.br/pdf?ep04041

[20] Niranjan, G.V. and Vasundhra, M.K. (1996) A Study of Health Status of Aged Persons in Slums of Urban Field Practice Area, Bangalore. Indian Journal of Community Medicine, 21, 37-40.

[21] Parasuramalu, B.G., Vastrad, S.A. and Shivaram, C. (1990) Prevalence of Anaemia in the Aged Population in Selected Slums of Hubli City. Indian Journal of Public Health, 34, 117-118.

[22] Awasthi, S. and Agarwal, S. (2003) Determinants of Childhood Mortality and Morbidity in Urban Slums in India. Indian Pediatrics, 40, 1145-1161. http://www.indianpediatrics.net/dec2003/dec-1145-1161.htm

[23] Ministry of Housing and Urban Poverty Alleviation (Government of India) (2008) Annual Report 2007-2008. Ministry of Housing and Urban Poverty Alleviation, New Delhi. http://mhupa.gov.in/match_column_frame.htm

[24] Ministry of Statistics and Programme Implementation (MoSPI) (Government of India) (2004) Highlights, Report No. 507: Morbidity, Health Care and the Condition of the Aged: January-June, 2004. Ministry of Statistics and Programme Implementation, New Delhi. http://mospi.nic.in/Mospi_New/upload/60R_25.0.pdf

[25] Agarwal, S., Sethi, V., Gupta, P., Jha, M., Agnihotri, A. and Nord, M. (2009) Experiential Household Food Insecurity in an Urban Underserved Slum of North India. Food Security, 1, 239-250. http://www.uhrc.in/downloads/Publications/Articles/food-security.pdf

[26] Agarwal, S., Bhanot, A. and Goindi, G. (2005) Understanding and Addressing Childhood Immunization Coverage in Urban Slums. Indian Pediatrics, 42, 653-663. http://indianpediatrics.net/july2005/july-653-663.htm

[27] Das, S., Bapat, U., More, N.S., Chordhekar, L., Joshi, W. and Osrin, D. (2010) Prospective Study of Determinants and 
Costs of Home Births in Mumbai Slums. BMC Pregnancy and Childbirth, 10, 38.

http://www.biomedcentral.com/1471-2393/10/38

http://dx.doi.org/10.1186/1471-2393-10-38

[28] Agarwal, S., Srivastava, K., Sethi, V., Mathur, M., Sanger, K., Halder, P. and Kaushik, S. (2007) Birth Practices in Underserved Urban Slum Dwellings of Indore, India. Poster Presentation No. 102, Poster Session 2: MDG-4 (Reduce Child Mortality-1), 11th Annual Scientific Conference of ICDDR.

http://uhrc.in//downloads/Presentations/BIRTH PRACTICES IN UNDERSERVED URBAN SLUM DWELLINGS _OF.pdf

[29] Chakarapani, S. (2007) Urban Health Care in India.

http://www.ananthapuri.com/article.asp?title=Urban-Health-Care-in-India\&id=44

[30] Singh, A.D., Taneja, S. and Agarwal, S. (2004) Technical Assistance to the Government of India for Urban Health Planning and National Guidelines. Activity Report 135, Environmental Health at USAID, Arlington. http://www.ehproject.org/PDF/Activity_Reports/AR-135\%20Guidelines\%20UH\%20India\%20Format.pdf

[31] Urban Health Resource Centre (UHRC) (2008) Ranbaxy XX Roundtable Conference on Improving Access of Healthcare to the Urban Poor in India. UHRC, New Delhi. http://www.uhrc.in/module-ContentExpress-display-ceid-67.html

[32] Islam, M., Montgomery, M. and Taneja, S. (2006) Urban Health and Care-Seeking Behavior: A Case Study of Slums in India and the Philippines. The Partners for Health Reform Plus Project, Abt Associates Inc., Bethesda.

[33] International Institute for Population Sciences (IIPS), \& Macro International (2007) National Family Health Survey (NFHS-3), 2005-06: India. Vol. I, IIPS, Mumbai.

[34] National Sample Survey Organization (NSSO) (Government of India) (2006) Morbidity, Health Care and the Condition of the Aged. Report No. 507, National Sample Survey Organization, Ministry of Statistics and Programme Implementation, New Delhi.

[35] International Institute for Population Sciences (IIPS), \& ORC Macro (2000) National Family Health Survey (NFHS-2), 1998-99, India. IIPS, Mumbai.

[36] National Sample Survey Organization (NSSO) (Government of India) (1998) Morbidity and Treatment of Ailments. Report No. 441, National Sample Survey Organisation, Department of Statistics, New Delhi.

[37] Ministry of Health and Family Welfare (MoHFW) (Government of India) (2005) Report of the National Commission on Macroeconomics and Health. Ministry of Health and Family Welfare, New Delhi.

[38] Gupta, I. and Mitra, A. (2002) Basic Amenities and Health in Urban India. The National Medical Journal of India, 15, 26-31.

[39] Gupta, I., Mitra, A. and Jha, M. (1998) Slum Dwellers in Delhi: An Unhealthy Population. IEG Working Paper No. E/ 194/98, Institute of Economic Growth, Delhi.

[40] Sengupta, A. and Nandy, S. (2005) The Private Health Sector in India. British Medical Journal, 331, 1157-1158. http://www.bmj.com/cgi/content/extract/331/7526/1157 http://dx.doi.org/10.1136/bmj.331.7526.1157

[41] Duggal, R. (n.d.) The Private Health Sector in India: Nature, Trends and a Critique. Centre for Enquiry into Health and Allied Themes, Mumbai. http://www.cehat.org/publications/ra01r6.html

[42] Kumar, S. (2003) Health Care Is among the Most Corrupt Services in India. British Medical Journal, 326, 10. http://www.bmj.com/cgi/content/extract/326/7379/10/c http://dx.doi.org/10.1136/bmj.326.7379.10/c

[43] World Bank (2008) World Bank and Government of India Agree Action to Stamp out Health Project Fraud and Corruption. Press Release No:2008/234/SAR. World Bank, Washington DC. http://www.worldbank.org.in/WBSITE/EXTERNAL/COUNTRIES/SOUTHASIAEXT/INDIAEXTN/0,,contentMDK: 21686068 menuPK:295603 pagePK:2865066 piPK:2865079 theSitePK:295584,00.html

[44] Sinha, K. (2012) CAG to Audit NRHM Scheme in 18 States. The Times of India, New Delhi. http://articles.timesofindia.indiatimes.com/2012-02-01/india/31012522_1_cag-audit-accountant-generals-concurrent-au $\underline{\text { dit }}$

[45] Dash, D.K., Lalchandani, N. and Pandit, A. (2009) Mayor May Seek CBI Probe into Fake MCD Staff Scam. The Times of India, New Delhi. http://timesofindia.indiatimes.com/Cities/Delhi/Mayor-may-seek-CBI-probe-into-fake-MCD-staff-scam-/articleshow/4 722289.cms

[46] Ghanashyam, B. (2008) Can Public-Private Partnerships Improve Health in India? The Lancet, 372, 878-879. http://dx.doi.org/10.1016/S0140-6736(08)61380-X 
[47] Melby, B., Dagur, V. and Switlick-Prose, K. (2012) Making the Indian Health System Work for the Urban Poor: Strategies for Extending Financial Risk Protection and a Continuum of Healthcare. Health Systems 20/20 Project, Abt Associates Inc., Bethesda.

[48] Ministry of Housing and Urban Poverty Alleviation (MoHUPA) (Government of India) (2011) Report of the Working Group on Urban Strategic Planning. Ministry of Housing and Urban Poverty Alleviation, New Delhi. http://planningcommission.nic.in/aboutus/committee/wrkgrp12/hud/wg_rep_Urban_WG.pdf 
Scientific Research Publishing (SCIRP) is one of the largest Open Access journal publishers. It is currently publishing more than 200 open access, online, peer-reviewed journals covering a wide range of academic disciplines. SCIRP serves the worldwide academic communities and contributes to the progress and application of science with its publication.

Other selected journals from SCIRP are listed as below. Submit your manuscript to us via either submit@scirp.org or Online Submission Portal.
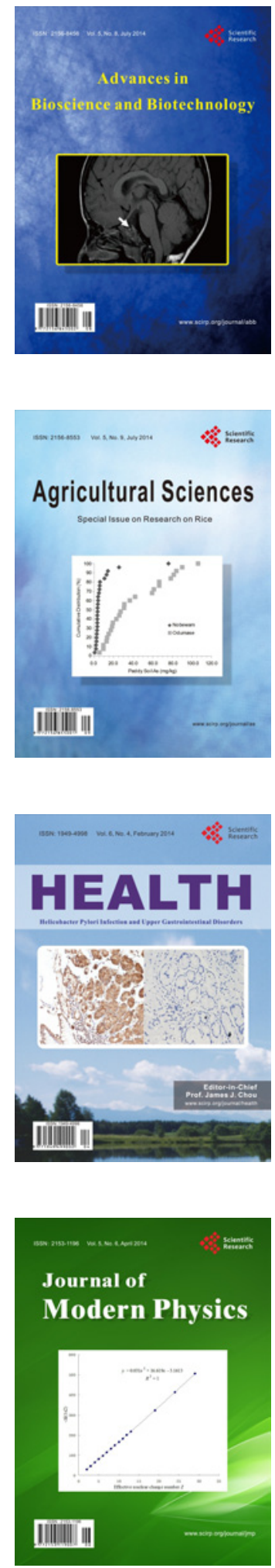
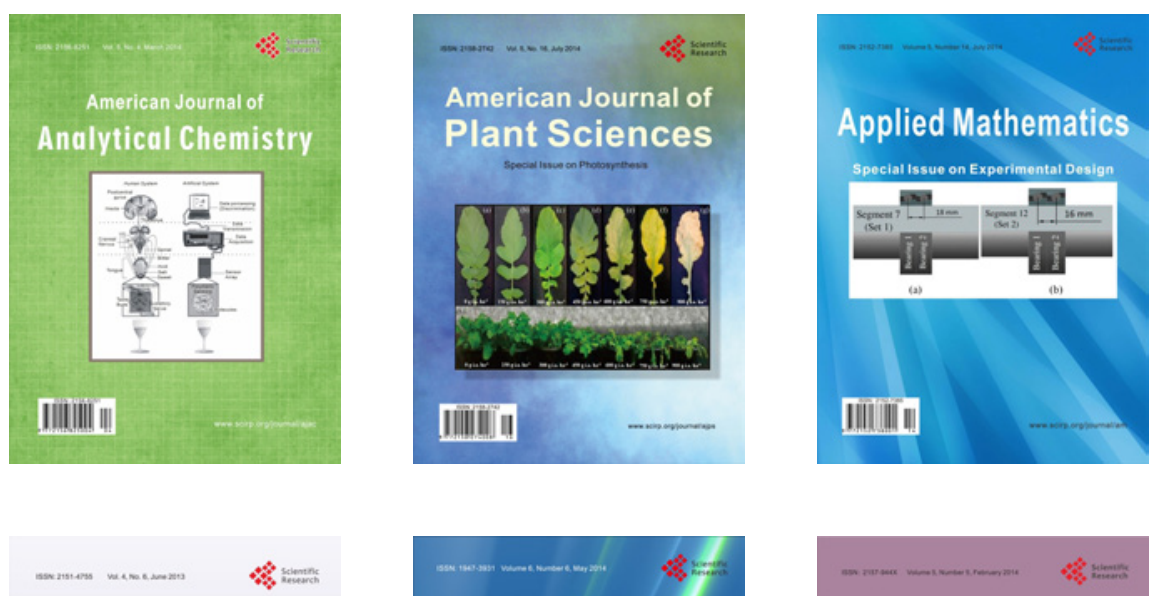

Creative Education
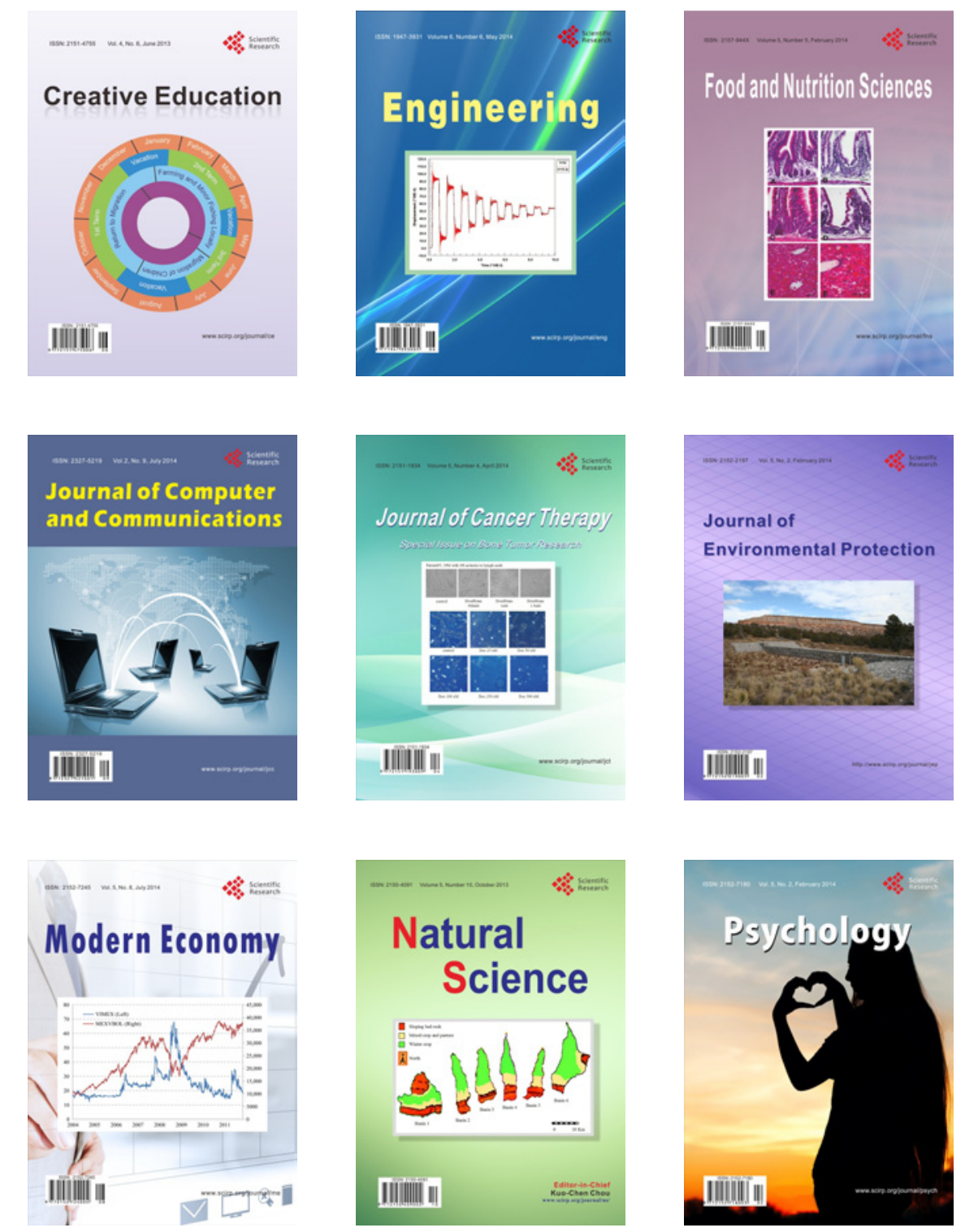